\title{
Youth Engagement in Electoral Activities: A Collaborative Evaluation of a Civic Education Project
}

\author{
Michael J. Berson ${ }^{1}$, Liliana Rodríguez-Campos ${ }^{2}$, Connie Walker-Egea ${ }^{2}$, Corina Owens ${ }^{2} \&$ Aarti Bellara $^{2}$ \\ ${ }^{1}$ Department of Secondary Education, University of South Florida, USA \\ ${ }^{2}$ Department of Educational Measurement and Research, University of South Florida, USA \\ Correspondence: Michael J. Berson, Department of Secondary Education, University of South Florida, 4202 E \\ Fowler Ave, EDU 105, Tampa FL, USA.
}

Received: July 19, 2013 Accepted: August 13, 2013 Online Published: October 21, 2013

doi:10.11114/jets.v2i1.243 URL: http://dx.doi.org/10.11114/jets.v2i1.243

\begin{abstract}
Youth civic engagement is recognized as an essential component necessary for the preservation of democratic practices; however, inadequate levels of civic participation persist among young people. Past research has shown that young people are more likely to participate in politics when they are informed. We present survey data collected from middle and high school students during a collaborative evaluation of a civic education project. A total of 4492 students participated in the pre-survey, and 3180 students participated in the post-survey. The aim of this part of the evaluation was to explore students' civic engagement before and after the infusion of civic education into the curriculum. We discuss reasons hindering students' intent to vote, their satisfaction level with the 2008 presidential election, and how students planned to become involved in the 2012 presidential election. The results of the post-survey show an increase in students registered to vote and students' intent to register to vote after the infusion of civic education into the curriculum. The findings suggest that civic education seems to positively influence students' political behavior.
\end{abstract}

Keywords: civic education, youth civic engagement, electoral activities, political engagement, voting, program evaluation

\section{Introduction}

Youth civic engagement is recognized as an essential piece to preserve democratic practices. Nonetheless, the decline in civic engagement has been pervasive among young people, those aged 18 to 25 (Bermúdez, 2012; Bos, Williamson, Sullivan, Gonzales, \& Avery, 2007; Glasford, 2008; Utter, 2011), and these trends are particularly problematic in Florida. According to the 2011 Florida Civic Health Index report (Knuckey, Frey, Collie, \& Graham), the state ranked $48^{\text {th }}$ in the nation for youth civic engagement. Specifically, the political participation or electoral engagement of young Floridians is at or below the national average. Identification of the underlying reasons for youth disengagement in the democratic process may inform strategies that address challenges and foster the civic involvement of young people.

As part of the collaborative evaluation of a civic education project implemented in a large, urban school district in Florida, we collected survey data from middle and high school students (ranging from 11 to 21 years old) to determine their engagement in presidential electoral activities. We present information about students' commitment to registering to vote or their intent to participate in the election process and reasons hindering students' intent to vote, before and after the infusion of civic education into the curriculum. We describe students' satisfaction level with the 2008 presidential election and explain how students planned to become involved in the 2012 presidential election. The latter information was collected only in the post-survey, to help the evaluation capture further information about civic engagement after the 2008 presidential election.

Researchers have highlighted numerous explanations for the disproportionate disengagement of young voters relative to other age groups. Walker (2006) explained that young people split public engagement in two, the civic and the political world. Even though they are less likely to demonstrate interest in, feel responsible for, and identify with the political world, they tend to be engaged and involved in the community, helping others and volunteering in organizations. This dichotomization may occur because community involvement provides 
immediate gratification and concrete reinforcement of ideals. Conversely, there is no guarantee that political participation will render changes. This uncertainty makes young people skeptical about the political process, the influence they can have as political actors, and the competence of the people that are part of this process (Gainous \& Martens, 2012; Kelso \& Cogan, 2008). Therefore, there is a lack of trust in the efficacy of being involved in politics, which plays a crucial role in young people engaging in or opting out of electoral activities (Glasford, 2008). Also, young people feel marginalized within the political process and perceive government as ineffective and corrupt (López, Levine, Both, Kiesa, Kirby, \& Marcelo, 2006; Shea \& Green, 2007).

Moreover, political parties, campaigns, candidates, and advocacy groups see little reason to devote their resources to reach out to this group because they are less likely to vote (DelliCarpini, 2000; Richie, 2007; Utter, 2011). When civic organizations have attempted to pursue youth involvement, they have employed inefficient efforts with minimal gain (Gainous \& Martens, 2012; Utter, 2011). Consequently, the decline in civic engagement and low turn out to vote is directly associated with the relative lack of attention to the concerns of young adults. In other words, the political process ignores young people, so in turn, young people ignore the political process.

Finally, low participation may also result from inadequate quality and quantity of civic education in schools (DelliCarpini, 2000; Gainous \& Martens, 2012; Miklosi, 2007). Political illiteracy is prevalent among disenfranchised voters (Forrest \& Weseley, 2007; Jansen, 2011).Young people often lack information about how government works and even how to register and vote (Jansen, 2011; López et al., 2006). Hence, without acquired political knowledge either through personal experience, schools, community organizations, or other sources, the capacity for civic participation is diminished (Utter, 2011). Well informed voters ensure a productive democracy (Berman, 2003; Meirick \&Wackman, 2004), so adults need to foster a solid civic foundation for young people (Miklosi, 2007). "Improving education and improving democracy go hand in hand" (Glickman, 2009, p. 56).Unfortunately, the political socialization process, that is, the learning process by which children and adolescents obtain political knowledge and attitudes, has failed to achieve desired outcomes.

\section{The Civic Education Project}

The goal of the civic education project was to improve the quality of civic education in a large, Florida school district, through the implementation of innovative and comprehensive programs. The project team designed the programs to improve public knowledge, understanding, and support of the federal and state legislatures. The civic education project was based on the premise that exemplary civic education, which focuses on the role and function of the U.S. Congress and state legislatures, produces knowledgeable adults who confidently participate in the democratic process.

Prior to the implementation of the project, the County and its public schools exhibited alarming gaps in both the preparation for and participation in the democratic process. County voting patterns clearly showed that minority subgroups were disenfranchised and significantly overrepresented among those individuals who opted out of participation in elections. In addition, the County public schools did not adequately prepare students to understand the workings of participatory democracy, so students lacked the requisite skills, as knowledgeable citizens, to take part in the process. However, this phenomenon was not exclusive to this County. In recent years, the time spent on social studies and civic education in the classroom has decreased throughout the United States, but this downward trend has been especially notable across the state of Florida (Dobson, Fine, \& Henderson, 2009).

Before implementing this project, the County public schools sporadically infused civic education related activities within the elementary and middle school social studies curriculum, but offered no organized structure or professional development for teachers to incorporate high quality and relevant civic education in the classroom. There was no articulation across grade levels to assist teachers in planning lessons, and instruction typically lacked strategies to assist students in making connections to content. At the high school level, students might elect to take a civics course, but civic education was not part of the required social studies curriculum. In the planning for teacher professional development, the County public schools negated the pervasive disengagement of minority students groups from voter participation. Moreover, standardized assessments of teacher or student knowledge as it relates to social studies and civics did not exist. The civic education that took place in the County public schools operated in a "vacuum" with no formal accountability for either teachers or students. Given these existing challenges, the project was funded to provide social studies teachers with professional development that might improve the quality of civic education in the County public schools and evaluate the civic education curriculum.

According to the Florida Civic Health Index 2009 report (Dobson, Fine, \& Henderson), well-educated citizens 
are more likely to be involved in governance. The report identified civic education as a vehicle for enhancing the civic health of the state. Therefore, shifting civic education to the center of the social studies curriculum might boost students' knowledge and understanding of the role and function of the U.S. Congress and state legislatures. Applying this knowledge through active learning experiences that highlight relevant implications of the political process for students' lives, teachers may mobilize young learners to subsequently embrace their participatory roles as citizens.

Overall, the project provided participating teachers with the strategies and tools necessary to teach civics in the classroom, infused cultural competence to address the needs of minority students, and assessed teacher and student knowledge of civics. Specifically, among the resources provided by this civic education project was a summer institute for teachers and school administrators, including 5 days of training in the areas of civic education, U.S. politics, culturally relevant instructional practices, and leadership. This summer institute was offered before the 2008 presidential election. Also, the teachers received an interactive CD-ROM about civic education, a DVD series on democracy, model lessons plans, books, and other materials to integrate into instruction and enhance the learning experience in their classrooms. Throughout the school year, ongoing professional development occurred via face-to-face and virtual seminars and school-based professional learning communities.

A local educational channel filmed a Democracy Series, which introduced local, state, and federal representatives, and broadcasted the videos on three networks to reach the community, students, and parents. The featured U.S. Congressmen, State Legislators, and local government representatives introduced many of the civic education topics. By including the students' own elected officials, the video not only highlighted content on the workings of government but also supported classroom instruction with authentic examples of government in action. The videos explored how the students' participation in the political process contributed to policy and practice in the community, state, and nation.

Moreover, in order to create a new civic education support structure, the project established a civic education curriculum review team to analyze the existing civic education practices in the County public schools. The review team consisted of social studies teachers, district social studies supervisors, faculty and researchers from a local university, and personnel from the national Center for Information and Research on Civic Learning and Education. The review included an analysis of current practices and the development of new tools and strategies for teachers to guide the design and implementation of classroom activities. The conceptual framework of the new civic education curriculum was based on the National Standards for Civics and Government developed by the Center for Civic Education with support from the United States Department of Education. The review team also cross walked these frameworks with the Next Generation Florida Sunshine State Standards in Social Studies for all grades.

\section{Method}

\subsection{Instrumentation}

The civic engagement of students was assessed through pre- and post-survey questionnaires that were designed specifically for the collaborative evaluation of the project. These questionnaires included both closed and open-ended questions that were developed based on the nineteen core indicators of civic engagement from the Center for Information \& Research on Civic Learning \& Engagement (2006). These indicators are grouped into three categories: civic indicators, electoral indicators, and indicators of political voice. This article is focused solely on those questions related to the electoral indicators. These indicators are: (a) voting regularly; (b) persuading others regarding political issues; (c) displaying buttons, signs, or stickers; (d) making campaign contributions; and (e) volunteering for candidate or political organizations.

The pre-survey questionnaire consisted of seventeen questions, which included items on the demographics of respondents and self-reports of civic engagement across diverse areas of involvement. The information presented in this article includes data from two of the questions concerning electoral behavior: (a) Are you currently registered or planning to register to vote when you turn 18? and (b) If you do not plan to register to vote, why not? Overall, these questions represented a proxy of the importance students ascribed to voting, considering that a large amount of the participating students were not able to register to vote or actively engage in voting because of their age. The pre-survey was conducted before the 2008 presidential election and right before infusing civic education at the school level.

The post-survey questionnaire consisted of twenty questions. It included the questions developed for the pre-survey questionnaire and three additional questions that were not included in the pre-survey about electoral behavior to capture further information after the 2008 presidential election. The post-survey questions 
considered in this article include the ones from the pre-survey formerly presented and the three additional questions. These questions were: (a) Are you satisfied with the 2008 presidential election? (b) Why do you feel this way? (This question refers to the previous one), and (c) How are you planning to get involved in the next presidential election? The post-survey was conducted during the spring of 2009, following the 2008 presidential election and about seven months after infusing civic education at the school level.

\subsection{Participants}

The pre- and post-survey questionnaires were administered to middle and high school students across 50 public schools in the district in which the project was implemented. A total of 4492 students participated in the pre-survey, and 3180 students participated in the post-survey. In both administrations, 52\% of the sample was female. About $30 \%$ of participants identified themselves as Hispanic/Latino in both administrations. With regard to ethnicity, $42 \%$ identified themselves as White, $16 \%$ as Black/African American, and 14\% as Multiracial. Other ethnic groups --Asian, African, Caribbean/Non-Hispanic, European, and Middle Eastern-- consisted of 4\% or less of participants. The student participants in the pre-and post-survey ranged in age from 11 to 21 years $(M$ $=14.8$ ).

\section{Findings and Discussion}

\subsection{Electoral Behavior}

Although young voters have had the lowest voter turnout rates in U.S. history, the results of the post-survey show an increase in students registered to vote and students' intent to register to vote after the infusion of civic education into the curriculum (see Table 1). Specifically, a comparison of the results between the pre-survey and the post-survey indicates that there was a $0.6 \%$ increase of students that were already registered to vote and a $5.7 \%$ increase of students indicating that they plan to register when they turn 18 . In contrast, there was a $3.5 \%$ decrease of students saying that they are not sure about registering to vote, and a $2.1 \%$ decrease of students that do not plan on registering. These data show positive trends in each of these categories after the infusion of civic education into the curriculum. According to several authors (DelliCarpini, 2000; Gainous \& Martens; Glickman, 2009; 2012; López et al., 2006; Miklosi, 2007; Utter, 2011), the young people that are likely to participate in the political process are those better informed about civics and politics, meaning that a civics foundation should start as early as possible. On the other hand, these authors identify lack of knowledge as a major obstacle for civic and political participation.

Table 1. Students Currently Registered or Planning to Register to Vote

\begin{tabular}{|c|c|c|}
\hline & Pre-Survey & Post-Survey \\
\hline Response Option & $\%$ & $\%$ \\
\hline Yes, I am already registered & 3.9 & 4.5 \\
\hline Yes, I plan to register when I turn 18 & 73.8 & 79.5 \\
\hline I am not sure about registering & 10.7 & 7.2 \\
\hline No, I do not plan on registering & 6.3 & 4.2 \\
\hline I cannot register (non US citizen) & 2.5 & 2.2 \\
\hline No response & 2.9 & 2.4 \\
\hline
\end{tabular}

Note: Number of participants in the pre-survey $=4492$ and post-survey $=3180$.

\subsection{Disengaged Students}

Students also provided information about specific reasons hindering their intent to vote or to register to vote. The themes identified in both the pre- and post-survey were personal reasons, perceptions of the government, views on the voting process, perceived relevance of the outcomes of the voting process, and beliefs about citizen responsibilities. A summary of the results from both administrations follows, detailing some of the major obstacles for political involvement as reported by participating students.

Personal reasons why students remain disengaged included: they have other things to do, are too busy, do not have time, or are too lazy to get involved. Additional explanations were: parents do not vote, students feel pressure on who to vote for, respondents need to know why they should vote, they are not sure about registering to vote or do not know why they are not planning to register, voting depends on who the candidates are, they do not like the candidates, they do not want to vote or do not like politics, and voting is against religious beliefs.

Students' responses to questions about how they perceive the government indicated that the American system is 
rigid, it is better not to get involved with government issues, the government brings trouble, the government is not for the people anymore, they do not like the way things are done, and they do not trust the President (i.e., Presidents make things worse). They also said: the candidates rarely stick to their promises or ideas, they do not want to get wrapped up with a corrupt government, and they believe that the voting system is flawed and full of injustices.

Regarding the voting process the students indicated that they do not know how to vote, they need to know more information before becoming involved, they are unable to understand the platform of the candidates (i.e., too much information to comprehend or irrelevant issues seeded apathy), and they believe other people can choose the candidates. The youth described voting as confusing, complicated, boring, a hassle, useless, and a waste of time.

Concerning perceived relevance of the voting process, disengaged students said that they are not interested in or do not care for politics or voting, voting is not important, they do not like elections or voting, they do not believe in politics, and they are not involved or do not follow politics. Additional identified barriers to involvement were evident in responses such as: there are so many citizens so other people can be in charge, they do not feel the need to vote, one vote does not make a difference or does not count, and they do not care who the President is.

When reflecting on citizen responsibilities respondents recognized that they are aware that they may be called for jury duty, but few respondents expressed interest in serving in the military. Other reasons for opting out of civic engagement mentioned by the students were that they are not going to remain in the United States, they do not want to live in the United States, and they do not consider the United States their home.

\subsection{Satisfaction with the 2008 Presidential Election}

After the 2008 presidential election we surveyed students about their satisfaction with the results and inquired into the reasons for their level of satisfaction. The majority of the students indicated that they were very satisfied $(40.3 \%)$ or satisfied $(30.4 \%)$ with the 2008 presidential election. In contrast, $14.4 \%$ of the students indicated they were dissatisfied and $11.2 \%$ were very dissatisfied with the results. About $3.7 \%$ did not respond. These results correspond to those reported by CIRCLE (2008) in which about $68 \%$ of young voters strongly supported Barack Obama and the Democratic Party.

Students indicated a variety of reasons for their satisfaction or dissatisfaction with the election results. The students that were very satisfied said that the results of the election meant change; specifically, they believed that history was made with the selection of the first black president. They also expressed pride in the United States voters for supporting or believing in Obama, they wanted a Democrat in office, and they agreed with Obama's policies and platform --such as gay rights, abortion, education, taxes, gas prices, immigration, and war. Additional reasons were: the better candidate won, Obama will be a good leader and president, he will fix the economy, Obama is smart, Obama will help the middle and lower class families, and my parents were in favor of Obama.

Those that were satisfied expressed many of the same reasons previously attributed to the very satisfied respondents. Additionally, this group noted some ambivalence about the outcome commenting, Obama will be okay, they wanted Hilary but are satisfied with Obama, they wanted McCain but have faith in Obama, they did not like either candidate but Obama was the better of the two, they liked both candidates so it did not matter, and they wanted to see what Obama will do before being very satisfied.

Conversely, dissatisfied and very dissatisfied students expressed similar justifications for their discontent with the election outcome. The students that were dissatisfied indicated that they do not like Obama's policies --such as economics, gay rights, abortion, immigration, taxes, and war--, they wanted Hilary to win the Democratic nomination, they wanted McCain to win the election because McCain's plans would have benefited their family, and they did not like either candidate. Additional reasons for dissatisfaction were: Obama lacked experience and leadership skills, the perception that Obama had religious/terrorist ties, and a belief that people only voted for Obama because of his race.

\subsection{Involvement in the 2012 Presidential Election}

Students reported on their anticipated future civic engagement in the next election in the post-survey, with $40 \%$ of all respondents indicating that they are planning to vote in 2012 (see Table 2). Since some of the surveyed participants will not have reached voting age, other forms of involvement favored by students were persuading others to vote; campaigning for candidates; supporting candidates; attending or watching debates, speeches, lectures, and news; displaying buttons, signs, stickers, and t-shirts; and distributing flyers. These findings are similar to those reported in The 2006 Civic and Political Health of the Nation (López et al., 2006) in which 
voting; trying to persuade others to vote; following what is going on in government; and displaying campaign buttons, signs, stickers, and others were the most popular electoral indicators, among those aged 15 to 25 . Also, the findings of this evaluation showed that donating money to a candidate or party and volunteering for political candidates were among the least popular forms of involvement. These results were also similar to those reported by López et al. (2006). In addition, we found that $4.5 \%$ of respondents do not know what to do to get involved.

Table 2. Middle and High School Students' Plan to Get Involved in the 2012 Presidential Election as Reported in the Post-Survey

\begin{tabular}{|c|c|c|}
\hline Plan & $f$ & $\%$ \\
\hline \multicolumn{3}{|l|}{ Voting } \\
\hline Vote & 1288 & 40.5 \\
\hline Register to vote & 95 & 3.0 \\
\hline Vote at school/kids activities & 71 & 2.2 \\
\hline Vote/register when old enough & 31 & 1.0 \\
\hline Persuade others to vote & 219 & 6.9 \\
\hline \multicolumn{3}{|l|}{ Campaigning } \\
\hline Display buttons, signs, stickers, T-shirts, distribute flyers & 122 & 3.8 \\
\hline Support candidates, rallies, canvassing & 117 & 3.7 \\
\hline Donate money/raise funds & 14 & 0.4 \\
\hline \multicolumn{3}{|l|}{ Learning } \\
\hline Attend/watch debates, speeches, lectures, news & 121 & 3.8 \\
\hline Learn information about candidates & 110 & 3.5 \\
\hline \multicolumn{3}{|l|}{ Volunteering } \\
\hline Volunteer work (such as phone calls, poll station work, and register voters) & 62 & 2.0 \\
\hline \multicolumn{3}{|l|}{ Others } \\
\hline Not planning to get involved & 188 & 5.9 \\
\hline Do not know what to do & 143 & 4.5 \\
\hline Too young to get involved & 63 & 2.0 \\
\hline Cannot get involved (not American citizen) & 18 & 0.6 \\
\hline No response & 849 & 26.7 \\
\hline
\end{tabular}

Note: Number of participants $=3180$. The data in this table was collected only in the post-survey, after the 2008 presidential election.

\section{Concluding Thoughts}

Moving students from apathy to action is of great importance in a democracy. By exploring reasons that hinder students from registering to vote or actively asserting their right to vote, educators and the community may identify strategies to increase the engagement of young people in electoral activities. Our data suggest that civic education seems to positively influence students' political behavior. After infusing civic education into the curriculum students were more likely to register to vote or plan to register to vote when they turn 18, but other factors could influence as well. Enhancement of the civic education curriculum through meaningful and relevant learning activities may facilitate connections to young people's concerns and promote engagement in a variety of civic activities, including voting.

Equally important is to offer teachers civic education training aligned to the curriculum content and the needs of the students. It is important to make available to teachers information regarding how students think and feel about the electoral process. This information could be used to direct efforts toward the improvement of students' negative attitudes or misguided beliefs about the electoral system and the government, and could motivate students that are currently disinterested in participating in electoral activities to become engaged. Even though education is not the only means to address the low youth commitment to participate in the electoral process, it seems to be crucial to increase awareness and understanding of the role and importance of voting and other democratic practices.

\section{References}

Berman, S. H. (2003). Practicing democracy in high school. Educational Leadership, 61(1), 35-38.

Bermúdez, A. (2012). Youth civic engagement: Decline or transformation? A critical review. Journal of Moral 
Education, 41(4), 529-542. http://dx.doi.org/10.1080/03057240.2012.732296

Bos, A. L., Williamson, I., Sullivan, J. L., Gonzales, M. H., \&Avery, P. G. (2007). The price of rights: High school students' civic values and behaviors. Journal of Applied Social Psychology, 37(6), 1265-1284. http://dx.doi.org/10.1111/j.1559-1816.2007.00212.x

Center for Information \& Research on Civic Learning \& Engagement. (2006). Core indicators of civic engagement. Retrieved from http://www.civicyouth.org/practitioners/Core_Indicators_Page.htm\#1

Center for Information \& Research on Civic Learning \& Engagement. (2008). Young voters in the 2008 presidential election. Retrieved from http://civicyouth.org/PopUps/FactSheets/FS_08_exit_polls.pdf

DelliCarpini, M. X. (2000). Gen.com: Youth, civic engagement, and the new information environment. Political Communication, 17(4), 341-349. http://dx.doi.org/10.1080/10584600050178942

Dobson, L. D., Fine, T. S., \& Henderson. A. L. (2009). Florida civic health index: Communities and the state's civic destiny. Retrieved from http://www.loufrey.org /include/files/programs/2009civicHealthIndex.pdf

Forrest, A. L., \& Weseley, A. J. (2007). To vote or not to vote? An exploration of the factors contributing to the political efficacy and intent to vote of high school students. Journal of Social Studies Research, 31(1), 3-11.

Gainous, J., \& Martens, A. M. (2012). The effectiveness of civic education: Are "good" teachers actually good for "all" students? American Politics Research, 40(2), 232-266. http://dx.doi.org/10.1177/1532673X11419492

Glasford, D. E. (2008). Predicting voting behavior of young adults: The importance of information, motivation, and behavioral skills. Journal of Applied Social Psychology, 38(11), 2648-2672. http://dx.doi.org/10.1111/j.1559-1816.2008.00408.x

Glickman, C. (2009). Educating for citizenship: A system wide responsibility for preparing students to become wise citizens. Educational Digest, 74(8), 50-56.

Jansen, B. A. (2011). Civic education and the learning behaviors of youth in the online environment: A call for reform. Journal of Social Studies Education Research, 2(2), 22-42.

Kelso, T., \& Cogan, B. (Eds.). (2008). Mosh the polls. Lanham, MD: Lexington Books.

Knuckey, J., Frey, L., Collie, T., \& Graham, B. (2011). 2011 Florida civic health index: The next generation. Retrieved from http://floridacitizen.org/wp-content/uploads/2012/01/CHI2011_Final_010512.pdf

López, M. H., Levine, P., Both, D., Kiesa, A., Kirby, E., \& Marcelo, K. (2006). The 2006 civic and political health of the nation. Retrieved from http://www.civicyouth.org/PopUps /2006 _CPHS _Report_update.pdf

Meirick, P. C., \&Wackman, D. B. (2004). Kids voting and political knowledge: Narrowing gaps, informing votes. Social Science Quarterly, 85(5), 1161-1177. http://dx.doi.org/10.1111/j.0038-4941.2004.00269.x

Miklosi, J. (2007). Respecting, listening, and empowering: Three vital factors for increasing civic engagement in American teenagers. National Civic Review, 96(2), 36-41. http://dx.doi.org/10.1002/ncr.176

Richie, R. (2007). Leave no voter behind: Seeking 100 percent voter registration and effective civic education. National Civic Review, 96(3), 39-45. http://dx.doi.org/10.1002/ncr.186

Shea, D. M., \& Green, J. C. (2007). Fountain of youth: Strategies and tactics for mobilizing America's young voters. Lanham, MD: Rowman \& Littlefield Publishers.

Utter, G. H. (2011). Youth and political participation: A reference handbook. Santa Barbara, CA: ABC-CLIO.

Walker, T. (2006). "Make them pay attention to us": Young voters and the 2004 election. National Civic Review, 95(1), 26-33. http://dx.doi.org/10.1002/ncr.128

\section{(cc) $\mathrm{Br}$}

This work is licensed under a Creative Commons Attribution 3.0 License. 